\title{
The Canning of Green Bananas. II. Internal Corrosion of Plain Tin Containers by the Acidified Green Bananas ${ }^{1}$
}

\author{
F. Sánchez-Nieva, C. E. Bueso and M. Mercado ${ }^{2}$ \\ ABSTRACT
}

Green bananas, acidified in the can with citric acid in a $2 \%$ brine and canned in plain tin cans (.75 lbs/BB inside), were spoiled by complete detinning of the containers when stored at ambient temperature $\left(85-90^{\circ} \mathrm{F}, 29.4-32.2^{\circ} \mathrm{C}\right)$ for 3 months.

The processed green bananas had a $\mathrm{NO}_{3}$ as $\mathrm{N}$ content ranging from 243 to $417 \mathrm{p} / \mathrm{m}$. In green banana pulp dispersions in citrate and acetate buffers canned in plain tin containers, $1 \mathrm{p} / \mathrm{m} \mathrm{NO}$ as $\mathrm{N}$ dissolved approximately 26 $\mathrm{p} / \mathrm{m} \mathrm{Sn}$. The high nitrate content of the green bananas was undoubtedly the main factor involved in the detinning of the containers. Water blanching under different conditions of time and temperatures failed to lower the nitrate content of the green bananas. Canning of the acidified green bananas in $\mathrm{F}$ enamellined cans did not prove feasible because of the rapid dark discoloration resulting a short time after the cans were opened.

\section{INTRODUCTION}

As part of the studies conducted by Sánchez-Nieva and Mercado (17) to determine the effect of different processing factors on the acidification of green bananas, over a hundred experimental packs were canned in plain tin cans. During storage at ambient temperature most of the lots suffered extensive detinning, finally developing hydrogen swells in periods ranging from 3 to 6 months.

Many factors are involved in the detinning of cans, such as the corrosive nature of the product, initial oxygen content, $\mathrm{pH}$, types of organic acid present, tin coating and storage temperature. Detinning finally leads to hydrogen swells and perforation of the container (7).

Nitrates have been found to be one of the primary causes of detinning in the canning of tomatoes $(6,8,10)$, carrots and green beans (4) sweet potatoes (18), grapefruit juice $(15)$, papayas $(2,13)$ and bananas (9). Iwamoto et al. (9) related the rapid detinning of cans of a banana drink to the nitrate content of the fruit, which they found to range from 4 to $30 \mathrm{p} / \mathrm{m}$.

${ }^{1}$ Manuscript submitted to Editorial Board December 2, 1981.

${ }^{2}$ Chemical Engineer (retired); Associate Professor, Department of Home Economics, University of Puerto Rico, Río Piedras Campus, formerly Associate Food Technologist; and Production Manager, NUMAR, Inc., Aguadilla, P. R., formerly Research Assistant, respectively, Food Technology Laboratory, Agricultural Experiment Station, Mayagüez Campus, University of Puerto Rico, Rio Piedras, P. R. The staff of the Corozal Substation and Mr. R. Guadalupe of the Food Technology Laboratory of the Agricultural Experiment Station assisted in the establishment, cultivation and harvesting of the banana plot used to provide green fruit for these studies. 
The nitrate detinning reaction has been extensively studied. $(4,5,19)$. This reaction is accelerated at low $\mathrm{pH}$ and in the presence of citrates ( 5 , 19). Since nitrates had already been implicated in the detinning of containers of banana products (9), and since the conditions under which the acidified bananas were canned-a low $\mathrm{pH}$ of 4.1 and the presence of citric acid in the brine-would favor this reaction, it was suspected that the detinning observed was related to the presence of nitrates.

\section{MATERIALS AND METHODS}

Green fruit of the Montecristo cultivar was used in this study. In the early part of this reasearch the fruit was purchased from a ripening plant when it ranged from three quarters to full ripe. The fruit was either processed the same day it was purchased or stored at $45^{\circ} \mathrm{F}\left(7.3^{\circ} \mathrm{C}\right)$ until used. For later studies, and in particular for those in which the effect of stage of development of the fruit at harvest on the stability of the canned product was determined, an experimental plot of 200 plants of Montecristo bananas was established at the Corozal Substation. The procedures followed in the production and harvesting of this plot have been described by Sánchez Nieva and Mercado (16).

Blanching and canning procedures were those described by Sánchez Nieva et al. in the first paper of this series (17).

To determine the relationship of nitrate lost to detinning the following procedure was followed: frozen hot water-peeled green bananas were thawed at room temperature and dispersed in citrate and acetate buffers to obtain pulp dispersions in the ratio of $1: 2,1: 3$ and 1:4 parts pulp to buffer solution. The dispersions were heated to $180^{\circ} \mathrm{F}\left(82^{\circ} \mathrm{C}\right)$ in a water bath and canned in plain tin (.75 lb tin/BB inside) $211 \times 304$ cans, with $\mathrm{C}$ enamel ends. The sealed cans were processed 30 minutes in boiling water, cooled under running tap water and stored at ambient temperature.

$\mathrm{pH}$ and total solids were determined by AOAC official methods (4). Tannins were determined by the method described by Leonard et al. (12) and calculated as mg tannic acid/100 g fresh weight.

Tin content was determined in the whole contents of the can. In the early part of these investigations tin content was determined by atomic absorption (3) and later by iodometric titration (20). Iron content was determined in the whole content of the can by the AOAC procedure (14) after acid digestion of the samples (20).

Nitrate was determined by the specific ion method with an Orion Research Inc. model $407 \mathrm{~A}$ specific ion meter. ${ }^{3}$ The manufacturer's

\footnotetext{
${ }^{3}$ Trade names in this publication are used only to provide specific information. Mention of a trade name does not constitute a warranty of equipment or materials by the Agricultural Experiment Station of the University of Puerto Rico, nor is this mention a statement of preference over other equipment or materials.
} 
instructions for nitrate measurement were followed. Nitrate content is expressed as $\mathrm{p} / \mathrm{m}$ nitrogen on a dry or wet basis as indicated.

\section{RESULTS AND DISCUSSION}

In the course of these studies a large number of experimental packs were canned, mostly fruit purchased from a local ripening plant. In these packs the internal corrosion of the tin plate container varied within wide limits. Some packs showed a shelf life of nearly a year, exhibiting only mild detinning, while other packs were more aggressive, completely detinning the containers in 2 months.

In 1978 all experimental packs were produced from sun-grown bananas produced at the Corozal Substation, harvested at different stages of development, as indicated by the pulp to peel ratios. All canned samples detinned the containers almost completely during a period of storage of

TABLE 1. - Tin content of canned acidified green bananas stored at $85-90^{\circ} \mathrm{F}\left(29.4-32.2^{\circ} \mathrm{C}\right)$ for 30 and 90 days

\begin{tabular}{cccc}
\hline $\begin{array}{c}\text { Pulp:peel } \\
\text { ratio } \\
\text { interval }\end{array}$ & $\begin{array}{c}\mathrm{NO}_{3} \text { as } \mathrm{N} \\
\text { in fresh } \\
\text { fruit }\end{array}$ & \multicolumn{2}{c}{$\begin{array}{c}\text { Sn content after storage for } \\
30 \text { days }\end{array}$} \\
\hline$<1.0-1.00$ & $p / m$ & $p / m$ & $p / m$ \\
$1.01-1.10$ & 417.1 & 208.7 & 339.0 \\
$1.21-1.30$ & 408.1 & 222.5 & 338.0 \\
$1.31-1.40$ & 340.4 & 158.6 & 257.0 \\
$1.41-1.50$ & 351.8 & 201.6 & 328.6 \\
$1.51-1.60$ & 320.5 & 173.5 & 297.5 \\
$1.61-1.70$ & 419.3 & 189.6 & 315.3 \\
\hline
\end{tabular}

90 days or less at 85 to $90^{\circ} \mathrm{F}\left(29.4\right.$ to $\left.32.2^{\circ} \mathrm{C}\right)$. Table 1 shows the tin content of canned samples of green bananas harvested at different stages of development. After 90 days of storage, for practical purposes, the cans were completely detinned, the tin content of the homogenized can product approaching the free tin content of the container used. Corrosion proceeded rapidly after detinning, with the formation of springers and hydrogen swells and finally perforation of the containers. The following tabulation shows the increase in Fe content in 2 lots during storage at ambient temperature.

$\begin{array}{cc}\text { Sample } & \text { Days stored } \\ 1 & 105 \\ & 119 \\ 2 & 129 \\ & 112 \\ & 126 \\ 136\end{array}$

Fe content, $p / m$

62.3

75.85

72.45

80.5

94.1

108.9 
After 90 days of storage, sample 1 had a tin content of $359 \mathrm{p} / \mathrm{m}$; and sample 2, 233.9 .

Table 1 also shows the nitrate as $\mathrm{N}$ content of the processed fruit. In all samples the nitrate content was very high exceeding the level of 100 $\mathrm{p} / \mathrm{m}$, which was found by Farrow et al. (6) to constitute a serious detinning problem in canned tomatoes.

To establish the probable relationship of the high nitrate content with detinning, banana pulp dispersions, in citrate and acetate buffered at a $\mathrm{pH}$ range similar to the stabilization $\mathrm{pH}$ of the acidified canned bananas (4.1), were canned in plain tin cans (.75/.25). Table 2 shows the initial nitrate as $\mathrm{N}$ content in these samples and the dissolved tin content after storage for 70 days at ambient temperature. For practical purposes the containers were completely detinned during this short storage period, also with a loss of nitrate (table 2). The amount of tin dissolved corresponded to a loss of nitrates, ranging from 23.88 to 29.42 , with an average of 26.35 for all samples, which approaches the value of $30 \mathrm{p} / \mathrm{m}$ tin dissolved per part nitrate as $\mathrm{N}$ reported for bananas by Iwamoto et al. (9).

Not only the high nitrate content in the processed green bananas favored the rapid corrosion of the containers, but also the $\mathrm{pH}$ of the canned acidified samples, which ranged from 4.0 to 4.4 , lies within the range at which the detinning reaction by nitrates have been found to be more aggressive (5).

Iwamoto et al. (9) found no relation of nitrate content to ripeness in bananas. However, in green bananas was found a highly significant correlation of pulp to peel ratios, which indicate the stage of development at harvest with nitrate and nitrogen content $(Y=494.95-142.33 X)$; the nitrate content decreases as the fruit develops. No significant correlation was found between age at harvest and nitrate content.

After harvest of the banana plot which provided the fruit for these studies, followers were allowed to develop for a second harvest. Unfortunately, two hurricanes which barely missed the Island of Puerto Rico in 1979 destroyed the plants. Luckily, five bunches at different stages of development could be harvested before the plants were destroyed. Table 3 shows the nitrate content of these bunches. All bunches had a much lower nitrate content than those harvested the previous year (table 1).

Even at these lower nitrate levels the acidified green bananas corroded the tin containers, rapidly reducing the shelf life of the product. Table 4 shows the corrosion behaviour of three experimental packs canned in $1.0 / .25$ plain tin cans during storage for about 7 months. For all practical purposes the containers were completely detinned at the end of this storage period. The maximum permissible limits for tin in the canned food products is $250 \mathrm{p} / \mathrm{m}$, and that when more than $150 \mathrm{p} / \mathrm{m}$ Sn is in 
TABLE 2.-Effect of $\mathrm{NO}_{3}$ content on detinning by buffered green bananas pulp dispersions after storage for 70 days at $85-90^{\circ} \mathrm{F}\left(29.4-32.2^{\circ} \mathrm{C}\right)$

\begin{tabular}{|c|c|c|c|c|c|c|}
\hline Pulp dilution & $\mathrm{pH}$ & $\begin{array}{l}\text { Initial N-NO }{ }_{3}{ }^{1} \\
\text { content }\end{array}$ & $\mathrm{N}-\mathrm{NO}_{3}$ lost & Sn content & $\mathrm{Fe}$ content & $\begin{array}{l}\text { Sn dissolved/ } \\
\mathrm{N}-\mathrm{NO}_{3} \text { lost }\end{array}$ \\
\hline \multicolumn{7}{|c|}{ Citrate buffer } \\
\hline & & $\mathrm{p} / \mathrm{m}$ & $\mathrm{p} / \mathrm{m}$ & $\mathrm{p} / \mathrm{m}$ & $\mathrm{p} / \mathrm{m}$ & $\mathrm{p} / \mathrm{m}$ \\
\hline $1: 2$ & 4.18 & 32.2 & 14.0 & 353.0 & 6.95 & 25.17 \\
\hline $1: 3$ & 4.30 & 25.3 & 10.7 & 255.0 & 6.04 & 23.92 \\
\hline $1: 4$ & 4.29 & 22.6 & 8.5 & 251.0 & 7.00 & 29.42 \\
\hline \multicolumn{7}{|c|}{ Acetate buffer } \\
\hline $1: 2$ & 4.28 & 28.7 & 11.7 & 351.0 & 8.09 & 29.04 \\
\hline $1: 3$ & 4.17 & 21.7 & 13.7 & 365.0 & 3.78 & 26.70 \\
\hline $1: 4$ & 4.19 & 20.3 & 13.3 & 317.0 & 1.52 & 23.88 \\
\hline
\end{tabular}

${ }^{1} \mathrm{~N}-\mathrm{NO}_{3}, \mathrm{Sn}$ and $\mathrm{Fe}$ contents are expressed as $\mathrm{p} / \mathrm{m}$ wet basis. 
solution the product is approaching an area of marginal acceptance (1); thus it is very unlikely that acidified bananas may be safely canned in plain tin containers.

The effect of hot water blanching on the nitrate content of bananas was explored. Tables 5 and 6 show the data obtained. Blanching for 5 minutes at temperatures ranging from 150 to $180^{\circ} \mathrm{F}\left(66\right.$ to $82^{\circ} \mathrm{C}$ ) and at $195^{\circ} \mathrm{F}\left(90.5^{\circ} \mathrm{C}\right)$ for a length of time ranging from 2 to 10 minutes, had no appreciable effect on the nitrate level. Tannins were slightly lowered by blanching.

TABLE 3.-Nitrate content of rattoon crop bananas

\begin{tabular}{cccc}
\hline Age at harvest & $\begin{array}{c}\text { Pulp:peel } \\
\text { ratio }\end{array}$ & Dry solids & $\begin{array}{c}\mathrm{N}-\mathrm{NO}_{3} \text { on } \\
\text { dry basis }\end{array}$ \\
\hline Days & & $\%$ & $p / m$ \\
75 & 1.00 & 25.98 & 127.60 \\
89 & 1.27 & 26.25 & 123.45 \\
95 & 1.23 & 26.28 & 133.80 \\
95 & 1.33 & 27.68 & 113.65 \\
102 & 1.58 & 26.52 & 99.5 \\
\hline
\end{tabular}

TABLE 4.-Detinning of 303 plain tin cans (1.0 lb. tin/BB inside) at ambient temperature $\left(85-90^{\circ} \mathrm{F} ; 29.4-32.2^{\circ} \mathrm{C}\right)$ by acidified green bananas ranging in $\mathrm{NO}_{3}-\mathrm{N}$ dry basis from 76.6 to $110.9 \mathrm{p} / \mathrm{m}$

\begin{tabular}{cccc}
\hline \multirow{2}{*}{ Storage time } & \multicolumn{3}{c}{ Tin content } \\
\cline { 2 - 4 } & $\mathrm{A}^{\mathrm{l}}$ & $\mathrm{B}$ & $\mathrm{C}$ \\
\hline Days & $p / m$ & $p / m$ & $p / m$ \\
2 & 65.4 & 59.7 & 61.0 \\
15 & 108.7 & 88.3 & 105.5 \\
35 & 122.6 & 136.5 & 124.4 \\
71 & 164.7 & 141.5 & 180.9 \\
159 & 258.5 & 206.7 & 295.5 \\
231 & 288.0 & 259.9 & 315.0 \\
\hline
\end{tabular}

${ }^{1} \mathrm{NO}_{3}-\mathrm{N}$ in fresh fruit, $\mathrm{p} / \mathrm{m}$ dry basis; $\mathrm{A}=76.6 ; \mathrm{B}=80.8 ; \mathrm{C}=110.9$.

A few lots of acidified green bananas were canned in $\mathrm{F}$ enamel-lined cans. Enamel failure was observed after storage for 90 days at room temperature. Dark spots in which the enamel had disappeared were observed on the bottom and top and along the side seam. After storage for 90 days the tin content in these samples was $27.1 \mathrm{p} / \mathrm{m}$ and the iron content $5.73 \mathrm{p} / \mathrm{m}$. After storage at ambient temperature for 170 days, the tin content increased to $52 \mathrm{p} / \mathrm{m}$ and the Fe content to $32.6 \mathrm{p} / \mathrm{m}$, indicating the failure of the enamel coating. The increase in iron content during the storage period was greater than that observed in samples canned in 
plain tin cans before the stage of complete detinning and corrosion. Brekke et al. (2) found a similar occurrence in canned papaya nectar, in which the iron content increased more rapidly in enamel-lined than in plain tin cans.

The bananas canned in the enamel-lined containers developed a strong discoloration a short time after the cans were opened. This behavior is typical of products having a high tannin content when canned in enamellined containers (11). This type of discoloration involves the formation of an iron tannin complex, which is colorless when the can is closed and the iron is in divalent state, but which turns dark on exposure to the air, when iron is oxidized to the trivalent state.

TABLE 5.-Effect of blanching temperature on the nitrate content of hot-water-peeled green bananas

\begin{tabular}{cccc}
\hline \multicolumn{2}{c}{ Blanching temperature } & Dry solids & $\mathrm{NO}_{3}-\mathrm{N}$ \\
Dry basis
\end{tabular}

TABLE 6.-Effect of time of blanching at $195^{\circ} \mathrm{F}\left(90.5^{\circ} \mathrm{C}\right)$ on the nitrate and tannin content of hot-water-peeled green bananas

\begin{tabular}{cccc}
\hline Time of blanching & Dry solids & $\begin{array}{c}\mathrm{NO}_{3}-\mathrm{N} \\
\text { Dry basis }\end{array}$ & $\begin{array}{c}\text { Tannins } \\
\text { Wet basis }\end{array}$ \\
\hline $\min$ & $\%$ & $p / m$ & $m g / 100 \mathrm{~g}$ \\
0 & 28.3 & 244.0 & 136.9 \\
2 & 27.5 & 219.0 & 95.0 \\
4 & 26.8 & 224.0 & 100.1 \\
6 & 27.3 & 179.0 & 76.1 \\
8 & 26.4 & 193.0 & 90.5 \\
10 & 27.2 & 244.0 & 87.8 \\
\hline
\end{tabular}

The results of these studies indicate that the high nitrate content of green bananas seems to be the primary factor involved in the detinning of the plain tin containers. Acidification with citric acid to a low $\mathrm{pH}(4.0)$ provided the ideal conditions for the nitrate detinning reaction to proceed at a very fast rate. The studies with buffer solutions, however, showed no appreciable difference in the rate of the detinning reaction when acetate buffer was used, so no appreciable difference in the detinning of the containers may be expected by substituting acetic for citric acid. 
The high nitrate content in most of the samples processed leads to the complete detinning in a short time apparently without exhausting the nitrates. This suggests that more nitrates were present than needed for complete detinning of the container. The nitrate-induced detinning will continue until either the nitrates or the tin is depleted (6); therefore the presence of so high a nitrate content in bananas prohibits the canning of this product in plain tin cans.

Since the high tannin content of green bananas favors the formation of dark iron tannin complexes which makes the product canned in enamel-lined containers unsalable, canning of the product in this type of container is not feasible either. There is the possibility that glass jars may prove to be a suitable container for packing green bananas, but at present we have no information on this matter.

As previously indicated, some processed bananas were low in nitrates. Of particular interest is the observation made that the sprouts (ratoon crop) of the experimental plots established at the Corozal substation had a much lower nitrate content than the fruit from the first harvest.

The accumulation of nitrates in tomatoes (8) has been associated with conditions of high temperature, high nitrogen fertilization and low light intensity. Nitrate reductase activity in green papaya was greatly increased by exposure to light (13). The interrelationship of all these factors in a tropical environment in which bananas are grown under widely varying conditions of light intensities, temperature and fertilizer regimes suggests that a fairly wide range of nitrate content may be expected in commercially harvested fruit.

\section{RESUMEN}

Como parte de un estudio para enlatar el guineo verde mediante acidulación y esterilización de los envases con agua hirviendo, se enlataron muestras en latas estañadas. En la mayor parte de estas muestras el estaño de la superficie interna se disolvió rápidamente. Todo el estaño libre se disolvió en 90 días; después se corroyó la placa y se hincharon las latas a causa de la liberación de hidrógeno. La disolución del estaño se atribuyó a que los guineos verdes enlatados tenían un alto contenido de nitratos que, en muchas muestras, fluctuó entre 243 a 417 ppm en términos de $\mathrm{N}$.

El contenido de nitratos en los guineos verdes disminuyó a medida que la fruta fue desarrollándose; se encontró una correlación significativa entre el contenido de nitratos y la razón de pulpa a cáscara. En muestras cosechadas con una proporción de fruta a cáscara de 1.0 a 1.7, el contenido de nitratos en términos de ppm de N fluctuó entre 417 y 243 ppm. 
Los resultados de ensayos en los cuales se prepararon y enlataron dispersiones del guineo verde en soluciones amortiguadas de citratos y de acetatos, demostraron que 1 ppm de nitrato como $\mathrm{N}$ disolvió alrededor de 26 ppm de estaño.

La escaldadura de los guineos verdes en agua a temperatura entre 150 y $180^{\circ} \mathrm{F}\left(66-82^{\circ} \mathrm{C}\right)$ por 5 minutos no afectó el contenido de nitratos. Tampoco tuvo efecto sobre los nitratos el escaldar el guineo verde a $195^{\circ}$ $\mathrm{F}$ por un periodo entre 2 y 10 minutos.

El enlatado de los guineos verdes acidulados en latas esmaltadas (esmalte F) no resultó factible, ya que los guineos se obscurecieron rápidamente al exponerse al aire cuando se abrieron los envases, posiblemente por la formación de complejos férricos y taninos.

\section{LITERATURE CITED}

1. Anon., 1973. Nitrate in foods, Food Technol. Aust. 25 (1): 10-13, 15-17.

2. Brekke, J. E., Cavaletto, C. G., Nayakama, T. O. M., and Suehisa, R. H., 1976. Effect of storage temperature and container lining on some quality attributes of papaya nectar, J. Agric. Food Chem. 24 (2): 341-43.

3. Cameron, A. G. and Britain, J. F., 1971. The measurement of tin in canned bean by atomic absorption spectrophotometry, J. Food Technol. 6 (2):187-92.

4. Farrow, R. P., Charbonneau, J. E. and Lao, N. T., 1966. The Tin Plate Producers C. M. I.-N. C. A. Research Program on Internal Can Corrosion, National Canners Association Research Foundation, Washington, D.C.

5. - - Lao, N. T. and Kin, E. S, 1970. The nitrate detinning reaction in model systems, J. Food Sci. 35 (6)812-22.

6. - - Johnson, J. H., Gould, W. A. and Charbonneau, J. E., 1971. Detinning in canned tomatoes by accumulation of nitrates in the fruit, J. Food Sci. 36:341-45.

7. Hartwell, R. Q., 1951 Corrosion factors related to the use of tin plate in food containers, Food Technol. 5 (10):402-8.

8. Hoff, J. E. and Wilcox, G. E., 1970. Accumulation of nitrate in tomato fruits and its effect on detinning, J. Am. Soc. Hort. Sci. 951 (1):92-4.

9. Iwamoto, Y., Miyasaka, M., Maeda, Y., and Herio, T., 1970. J. Jpn. Soc. Food Nutr., 23 (3): $213-17$.

10. Johnson, H. A., 1966. Internal can corrosion due to high nitrate content of canned vegetables, Fla. State Hort. Soc. Proc. 19:239-42.

11. Laboratory Manual for Food Canners and Processors, National Canners Association, Vol. 2, Chap. 25, p. 412, Avi Publishing Co. Westport, Conn., 1968.

12. Leonard, S., Luh, B. S. and Heinreiner, E., 1953. Flavor evaluation of canned Cling peaches, Food Technol. 7:480-85.

13. Lloyd, A. C., 1972. Nitrate and nitrate reductase in papaya fruit, Queensl. J. Agric. Anim. Sci. 29:85-102.

14. Official Methods of Analyses of the Association of Official Agricultural Chemists, 12th ed, Washington, D.C. 1975.

15. Saguey, I., Mannhein, C. H. and Parsy, N., 1973. The role of sulphur dioxide and nitrates on detinning of canned grapefruit juice, J. Food Technol. 8 (2):147-55.

16. Sánchez Nieva, F., Mercado, M. and Bueso, C., 1980. Effect of stage of development at harvest on the texture, flavor, quality and yields of green bananas, J. Agric. Univ. P. R. 64 (3):275-82. 
17. _- and —_, 1983. Studies on the canning of green bananas. I. Processing factors affecting the acidification of hot water peeled fruit, J. Agric. Univ. P.R. 67 (4):339-55.

18. Smittle, D. A. and Scott, L. E., 1969. Internal can corrosion by processed sweet potatoes as affected by phenolase activity and nitrate concentration, J. Am. Soc. Hort. Sci. 94 (6): 649-54.

19. Strodtz, N. H. and Henry, R. E., 1954. The relation of nitrate in foods to tinplate corrosion, Food Technol. 8 (2)93-5.

20. Townsend, C. T., Sommers, I. I., Lamb, F. C. and Olson, N. A., 1956. A laboratory Manual for the Canning Industry, National Canners Association, Berkely, Cal. 